\title{
Characterization of Glucose-6-phosphate-dependent Glycogen Synthase from Dictyostelium discoideum
}

\author{
By DAVID A. SAUNDERS AND BARBARA E. WRIGHT \\ Boston Biomedical Research Institute, 20 Staniford Street, Boston, \\ Massachusetts $02 \mathrm{I}_{4}$, U.S.A.
}

(Received I September 1976; revised 7 December 1976)

SUM M A R Y

Glucose-6-phosphate-dependent glycogen synthase from Dictyostelium discoideum was purified and characterized. Several nucleoside phosphates inhibited enzyme activity at their physiological concentrations (about $\mathrm{IO}^{-4} \mathrm{M}$ ). Glucose 6-phosphate and UDPglucose released these inhibitions at levels above their physiological concentrations. Unless compartmentation is invoked, experiments suggest that the glucose-6-phosphate-dependent enzyme is inactive in vivo.

\section{INTRODUCTION}

In Dictyostelium discoideum, the enzyme glycogen synthase (EC 2.4. I.II) plays an important role throughout the life-cycle. During growth of the vegetative myxamoebae, glycogen is synthesized and stored and is the major identifiable carbohydrate fraction (Rosness \& Wright, 1974; Hames \& Ashworth, 1974). Under starvation conditions, cellular glycogen levels remain relatively constant during the first half of the differentiation phase of the life-cycle. Thus, the rate of glycogen synthesis is comparable to the rate of glycogen degradation, catalysed by glycogen phosphorylase and amylase (Jones \& Wright, I970; Firtel \& Bonner, 1972; Marshall, Sargent \& Wright, 1970). At culmination (a stage of differentiation initiating the formation of the final fruiting body, or sorocarp), a net loss of glycogen occurs which is approximately equal in glucose units to the increase in the cellulose and trehalose content of sorocarps (Rosness \& Wright, 1974). An understanding of the regulation of glycogen synthase activity before and during the utilization of glycogen is therefore central to an analysis of the mechanisms responsible for the accumulation of the end products of differentiation.

Glycogen synthase has been partially purified and characterized (Wright \& Dahlberg, I967), and this study concentrates on the purification and extensive characterization of the glucose-6-phosphate-dependent form (D-synthase). Data have been obtained to determine the kinetic mechanism(s) of enzyme action according to Cleland's nomenclature (1963). A variety of enzyme effectors have also been investigated to assess the activity of the glucose6-phosphate-dependent form of the enzyme under physiological conditions.

In this paper, the terms D (glucose-6-phosphate dependent) and I (glucose-6-phosphate independent) simply refer to the effect of glucose 6-phosphate on enzyme activity. It is not known if they represent enzymically interconvertable forms similar to those observed in extensively characterized mammalian synthase systems. 


\section{METHODS}

Commercial materials. UDPglucose, glucose 6-phosphate, bovine serum albumin (BSA) and 3-( $N$-morpholino)propanesulphonic acid (MOPS) were obtained from Sigma; Tris was from Schwarz/Mann (Orangeburg, New Jersey, U.S.A.); EDTA from Fischer Scientific Co. (Fairlawn, New Jersey, U.S.A.); nucleoside mono-, di- and triphosphates from either Sigma or Calbiochem; and oyster glycogen from Calbiochem. UDP[U-14C]glucose was purchased from New England Nuclear; Superlose (potato amylose) was from Stein, Hall and Co. (New York, U.S.A.); and Cemusol NPT-I 2 from Melle-Bezons (95 Bezons, France).

Preparation of Dictyostelium glycogen. Myxamoebae starved for approximately $8 \mathrm{~h}$ were harvested in $0.045 \mathrm{M}$-glycine $/ \mathrm{NaOH}$ buffer, $\mathrm{pH} \mathrm{I}$, containing $0.15 \%$ (v/v) Cemusol NPT-I2. The cells were frozen and thawed, an equal volume of I M-acetic acid was added, and the mixture was heated at $100{ }^{\circ} \mathrm{C}$ for $20 \mathrm{~min}$. The extract was then centrifuged for Io $\min$ at $1400 \mathrm{~g}$ and the resulting supernatant fluid was mixed with 2 vols ethanol and heated for $5 \mathrm{~min}$ at $100{ }^{\circ} \mathrm{C}$. The glycogen thus precipitated was recovered as $1400 \mathrm{~g}$ pellets which were partially soluble in $\mathrm{I} \%(\mathrm{w} / \mathrm{v}) \mathrm{LiCl}$. The insoluble matter was centrifuged and discarded. The glycogen in the resulting supernatant fluid was precipitated and recovered as before, redissolved in $\mathrm{I} \% \mathrm{LiCl}$ and reprecipitated with ethanol. With this third precipitation, a fraction of glycogen which did not pellet at $1400 \mathrm{~g}$ was discarded. The pellet from the third ethanol precipitation was dissolved in water, dialysed against MOPS/EDTA buffer and used as substrate in the kinetic mechanism studies.

Preparation of Dictyostelium protein. Dictyostelium protein for 'cocktail' studies was prepared from the stages indicated in Table 3. The $122000 \mathrm{~g}$ supernatant fluid was obtained following the protocol for the preparation of the pellet enzyme. Protein was precipitated by adding an equal volume of $\mathrm{I} \mathrm{M}$-acetic acid and heating for $5 \mathrm{~min}$ at $100^{\circ} \mathrm{C}$. The precipitate was recovered at $27000 \mathrm{~g}$, redissolved in MOPS/EDTA buffer and dialysed against the same buffer. This preparation had no glycogen synthase activity.

Pellet enzyme preparation. This was modified from the method of Wright \& Dahlberg (1967). Differentiating cells of $D$. discoideum were harvested from plates of $2 \%(\mathrm{w} / \mathrm{v})$ agar containing 0.0I M-potassium phosphate pH 6.5 and 0.00I M-EDTA (Ward \& Wright, I965). The enzyme was prepared from culminating cells because preliminary investigations had indicated that this stage of differentiation had the highest ratio of D-synthase to I-synthase.

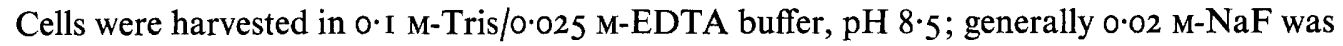
added to this buffer. The cells were kept frozen for I day to several weeks with little loss in activity.

On thawing, the cells were homogenized with a loose-fitting pestle, centrifuged at $27000 \mathrm{~g}$ for $\mathrm{I} 0 \mathrm{~min}$ and the supernatant fluid was again centrifuged for $\mathrm{I} h$ at $\mathrm{I} 22000 \mathrm{~g}$. At this speed the slime mould glycogen and D-synthase sedimented together. The pellet was resuspended in Tris/EDTA buffer and material that did not redissolve was removed by centrifuging at $2900 \mathrm{~g}$. The preparation at this stage was designated 'pellet enzyme'; it was stable for several weeks at $-20^{\circ} \mathrm{C}$.

Eluate enzyme preparation. For some experiments, an enzyme preparation was obtained by an affinity absorption procedure (Algranati \& Cabib, 1962; Wright \& Dahlberg, 1967). One $\mathrm{ml}$ of pellet enzyme (about $\mathrm{I} 2 \mathrm{mg}$ protein $\mathrm{ml}^{-1}$ ) was absorbed for $\mathrm{I}$ o $\mathrm{min}$ at room temperature on $100 \mathrm{mg}$ Superlose suspended in $1 \mathrm{ml}$ Tris/EDTA buffer. The Superlose was sedimented at $2900 \mathrm{~g}$ and washed three times in Tris/EDTA buffer. The enzyme was eluted by incubation for Io min at room temperature with $2 \mathrm{ml} 5 \%(\mathrm{w} / \mathrm{v})$ oyster glycogen in Tris/ EDTA buffer, and residual Superlose was removed by centrifugation. The enzyme at this 
purification stage was designated 'eluate'; its specific activity was comparable to that obtained by Wright \& Dahlberg (I967) and glycogen phosphorylase activity could not be detected. BSA was added to $0.1 \%(\mathrm{w} / \mathrm{v})$; such a stabilized preparation usually maintained its activity for 2 weeks at $-20^{\circ} \mathrm{C}$.

Ammonium sulphate fraction of the $122000 \mathrm{~g}$ supernatant fluid. For kinetic mechanism studies, an enzyme preparation from the $122000 \mathrm{~g}$ supernatant fluid was used. The supernatant fluid ( $17 \mathrm{mg}$ protein $\mathrm{ml}^{-1}$ ) and neutralized, saturated ammonium sulphate were slowly mixed at $0^{\circ} \mathrm{C}$ to a final concentration of $37.5 \%$ ammonium sulphate. After i $h$ at $\circ{ }^{\circ} \mathrm{C}$ the mixture was centrifuged at $27000 \mathrm{~g}$ and the pellet was redissolved in $7 \mathrm{ml}$ Tris/ EDTA and dialysed against the same buffer. BSA at $4 \mathrm{mg} \mathrm{ml}^{-1}$ was added to the final preparation (30 mg protein $\mathrm{ml}^{-1}$ ). Different preparations made following this protocol were variably dependent on glucose 6-phosphate; in the studies reported we used a preparation which became totally dependent after storage for several days at $-20{ }^{\circ} \mathrm{C}$. Such preparations depended entirely on added glycogen for activity. No $\alpha$-amylase activity was detected in this fraction. Stoicheiometry for UDP release and $\left[{ }^{14} \mathrm{C}\right]$ glucose incorporation into glycogen was examined. During $60 \mathrm{~min}$ incubation in the presence of high levels of oyster glycogen $(0.6 \%$ ) and UDPglucose $(3.3 \mathrm{~mm}), 0.21 \mu \mathrm{mol}$ UDP was formed and $0.16 \mu \mathrm{mol}$ glucose was incorporated.

Synthase assays. Glycogen synthase was determined by the incorporation of [U- $\left.{ }^{14} \mathrm{C}\right]$ glucose from UDPglucose into glycogen. The total reaction volume was $0.2 \mathrm{ml}$ and the buffer was $0.1 \mathrm{M}$-Tris $\mathrm{pH} 8.5$ or $0 . \mathrm{I}$ M-MOPS $\mathrm{pH} 6.4$, each with $0.025 \mathrm{M}$-EDTA. Unless otherwise stated, oyster glycogen was present at $0.25 \%$ and glucose 6 -phosphate at I mM. The UDPglucose concentration was either $3.3 \mathrm{~mm}\left(0 \cdot \mathrm{I} \mathrm{Ci} \mathrm{mol}^{-1}\right)$ or $0.1 \mathrm{~mm}\left(\mathrm{I} \mathrm{Ci} \mathrm{mol}^{-1}\right)$. The reactions were started by adding enzyme, incubated at room temperature, usually for 30 or $60 \mathrm{~min}$, and terminated by adding $0.2 \mathrm{ml} 10 \%(\mathrm{w} / \mathrm{v})$ trichloroacetic acid. If a visibly large amount of protein was precipitated by the trichloroacetic acid, the precipitate was centrifuged and washed once with $0.2 \mathrm{ml} 5 \%$ oyster glycogen and a second time with $0.2 \mathrm{ml} \mathrm{I} \%$ $\mathrm{LiCl}$; all supernatant fluids were combined. If a precipitate was not formed on addition of trichloroacetic acid, $0.2 \mathrm{ml} 0.5 \%(\mathrm{w} / \mathrm{v})$ carrier glycogen was added. The trichloroacetic acid-treated assay mixture (and washes, if present) was treated with 2 vols $95 \%(\mathrm{v} / \mathrm{v})$ ethanol and heated for $30 \mathrm{~s}$ in a boiling water bath. The glycogen precipitate thus formed was centrifuged at $2900 \mathrm{~g}$, redissolved in $\mathrm{I} \% \mathrm{LiCl}$ and reprecipitated. After two reprecipitations the glycogen was dissolved in water and counted in Aquasol (New England Nuclear) or Handifluor (Mallinckrodt). Counts were obtained to within $3 \%$ accuracy. A counting efficiency of $60 \%$ was used in calculations of absolute rates.

Kinetic mechanism studies. In these experiments the dependence of the glycogen synthase on both UDPglucose and glycogen was determined; the ammonium sulphate fraction was completely dependent on added glycogen for activity. The reaction mixture at $\mathrm{pH} 6.4$ in $0.08 \mathrm{M}$-MOPS/0.02 M-EDTA buffer was incubated for $10 \mathrm{~min}$. Varying amounts of Dictyostelium glycogen were added; the UDPglucose concentration was varied using a single dilution series $\left(0.2 \mathrm{Ci} \mathrm{mol}^{-1}\right)$. Initial rate studies at selected UDPglucose and glycogen concentrations indicated that linear rates were obtained under these conditions. Increases in glycogen levels during the assay were less than $0.3 \%$ and UDPglucose depletion amounted to less than $7 \%$. Background counts (generally less than $5 \%$ of the total) were subtracted in all cases; for a few low velocity measurements, the background was 10 to $20 \%$ of the observed total.

Analytical techniques. Glycogen was measured by the phenol-sulphuric acid method (Dubois et al., I956). UDP was assayed by Dr K. Killick according to Pontis \& Leloir 


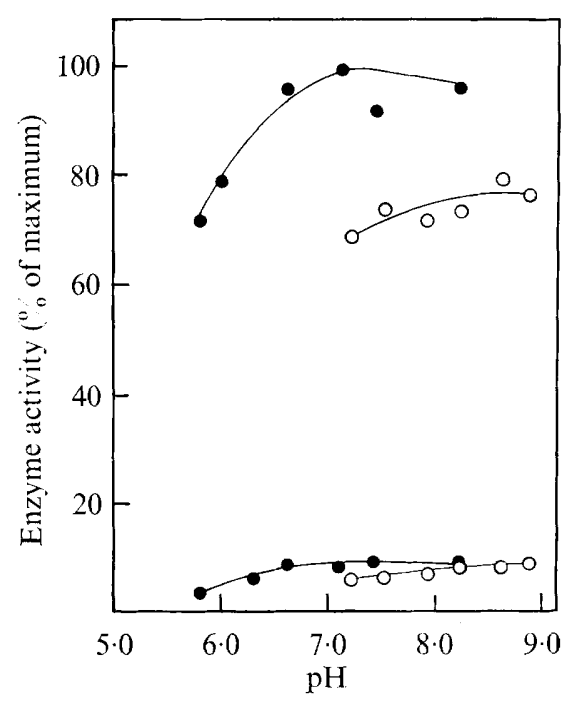

Fig. I. Effect of buffer and pH on eluate enzyme activity, with (upper two curves) and without (lower two curves) glucose 6-phosphate. (๑) MOPS buffer; $(O)$ Tris buffer.

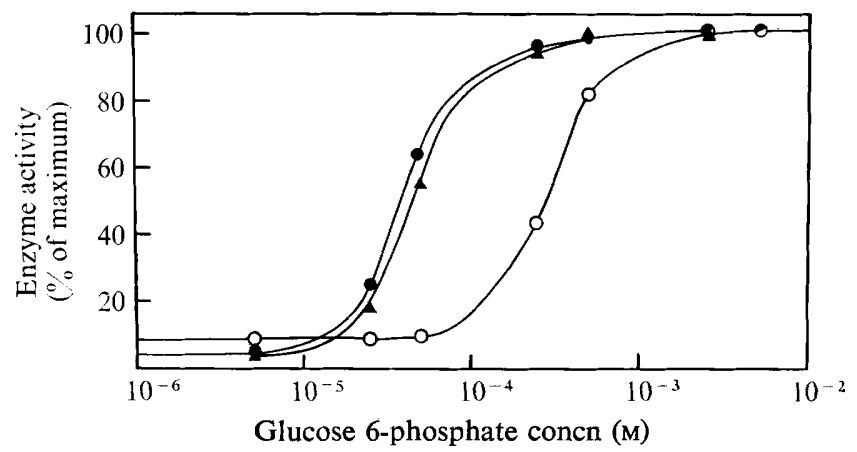

Fig. 2. Glucose 6-phosphate activation of eluate enzyme measured at: $(\bigcirc) \mathrm{pH} 8.5$ in Tris buffer with 3.3 mM-UDPglucose; (A) pH 6.5 in MOPS/EDTA buffer with 3.3 mM-UDPglucose; (৩) $\mathrm{pH} 6 \cdot 5$ in MOPS/EDTA buffer with O.I mM-UDPglucose.

(1962). Protein determinations were based on the Lowry method (Lowry, I957) with BSA as the standard. Eluate enzyme preparations had a low concentration of protein and a high concentration of glycogen which interfered with the assay; thus these samples were measured against BSA standards containing an appropriate concentration of glycogen.

Phosphorylase activity was determined by Dr D. Thomas according to Jones \& Wright (I970). $\alpha$-Amylase was determined by the method of Bernfeld (195I), except the buffer was MOPS/EDTA, pH 6.4.

\section{RESULTS}

Eluate enzyme was used for all the effector studies. The effect of $\mathrm{pH}$ on activity is shown in Fig. I. To determine kinetic effects under 'physiological' conditions, assays were done in MOPS/EDTA buffer at $\mathrm{pH} 6.4$ to 6.5 ; this is the optimum $\mathrm{pH}$ of the agar substratum, though the internal $\mathrm{pH}$ of the differentiating cells is not known. 
Table I. Effect of inorganic ions on glycogen synthase activity

For each salt, the cation is given in the column heading and the anion in the row heading: salt concentrations ( $\mathrm{M}$ ) are in parentheses. Activities are expressed as a percentage of the control activity, for no salt addition other than buffer. Eluate enzyme was assayed with $3.3 \mathrm{~mm}$-UDPglucose and I.25 mm-glucose 6-phosphate.

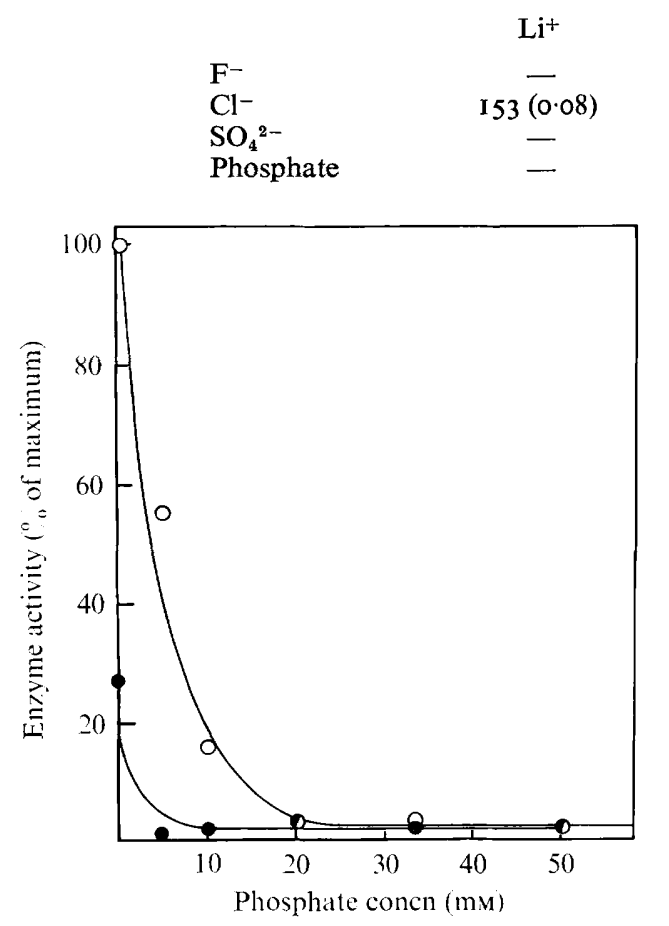

Fig. 3

$\begin{array}{cc}\mathrm{Na}^{+} & \mathrm{K}^{+} \\ \text {I26 (0.1) } & \text { I09 (0.2) } \\ \text { II }(0 \cdot 2) & 127(0 \cdot 2) \\ 6(0 \cdot 1) & 5(0 \cdot 05) \\ 6(0.03) & 7(0.03)\end{array}$

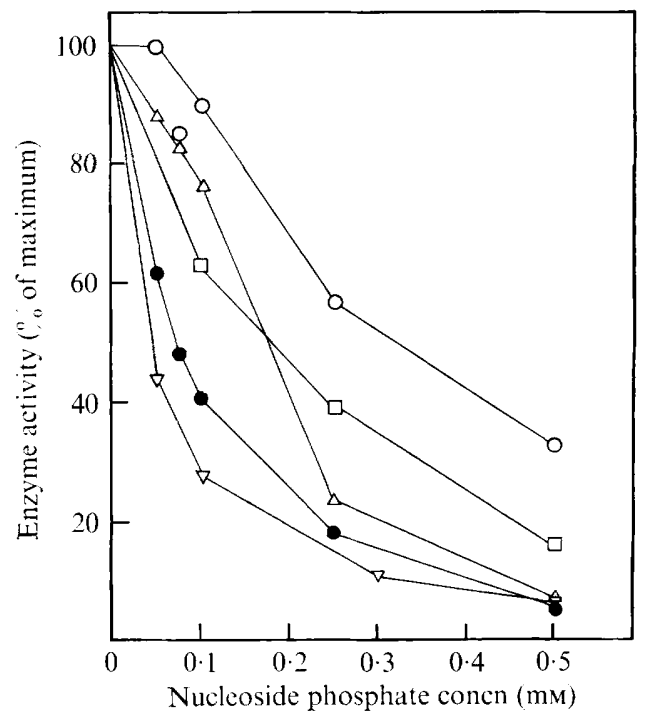

Fig. 4

Fig. 3. Phosphate inhibition of eluate enzyme activity with glucose 6-phosphate at $\mathrm{I} \cdot 25 \mathrm{~mm}(\mathrm{O})$ and $0.05 \mathrm{~mm}(\bullet)$. UDPglucose was at $0.1 \mathrm{~mm}$ for all determinations.

Fig. 4. Nucleoside phosphate inhibitors of eluate enzyme. UDPglucose was at $O \cdot I$ mM and glucose 6-phosphate at $0.05 \mathrm{mM} .(\bigcirc)$ UMP; $(\square)$ ATP; $(\triangle)$ UTP; $(\bullet)$ GTP; $(\nabla)$ UDP.

The effect of glucose 6-phosphate on enzyme activity at different pH values and UDPglucose concentrations is shown in Fig. 2.

Experiments on the effects of several inorganic ions on enzyme activity indicated that sulphate and phosphate are strong inhibitors and $\mathrm{Li}^{+}, \mathrm{Na}^{+}, \mathrm{K}^{+}, \mathrm{Cl}^{-}, \mathrm{F}^{-}$are activators (Table I). Since phosphate accumulates in Dictyostelium during differentiation (Wright, I973), this effector was examined more closely; in all studies, phosphate was neutralized to $\mathrm{pH} 7$ before addition to the assay mixture. Figure 3 shows the effect of phosphate over its range of physiological concentration. From the assays with $0.05 \mathrm{~mm}$-glucose 6 -phosphate, which is an average of its physiological range, it appears that the enzyme is completely inhibited in the range in vivo of UDPglucose, glucose 6-phosphate and phosphate.

Several nucleoside phosphates inhibited the enzyme over their physiological ranges at physiological concentrations of glucose 6-phosphate and UDPglucose (Fig. 4; Table 2). Cytosine phosphates were not tested since they cannot be detected in cell extracts (Rutherford \& Wright, I97I). Despite the variation with different enzyme preparations, all these compounds were apparently inhibitory below physiological concentrations, unless compart- 
Table 2. Effect of nucleoside phosphates at O. I $\mathrm{mM}$ on glycogen synthase activity

Activities are expressed as a percentage of the control activity, when no nucleotides were added.

\begin{tabular}{|c|c|c|c|c|c|c|c|c|c|c|}
\hline Assay conditions & ATP & ADP & AMP & GTP & GDP & GMP & UTP & UDP & UMP & UTP \\
\hline \multicolumn{11}{|c|}{$\begin{array}{l}\text { UDPglucose }(3.3 \mathrm{~mm}) \\
\text { Glucose 6-phosphate }(\mathrm{I} .25 \mathrm{~mm})\end{array}$} \\
\hline Eluate enzyme $2 / 12$ & IÓ & II I & 98 & 94 & 99 & 97 & 82 & IO4 & 98 & 45 \\
\hline Eluate enzyme $\mathrm{I} / 28$ & 77 & 49 & - & - & 46 & 105 & 100 & - & 102 & 100 \\
\hline \multicolumn{11}{|c|}{$\begin{array}{l}\text { UDPglucose }(0 \cdot 1 \mathrm{~mm}) \\
\text { Glucose 6-phosphate }(\mathrm{I} \cdot 25 \mathrm{~mm})\end{array}$} \\
\hline Eluate enzyme $2 / 12$ & 93 & 99 & IOI & 93 & 102 & 103 & 42 & 24 & 89 & 25 \\
\hline Eluate enzyme $\mathrm{I} / 28$ & 97 & - & 99 & 97 & - & 82 & - & - & - & 94 \\
\hline \multirow{2}{*}{\multicolumn{11}{|c|}{$\begin{array}{l}\text { UDP glucose }(0.1 \mathrm{mM}) \\
\text { Glucose 6-phosphate }(0.05 \mathrm{~mm})\end{array}$}} \\
\hline & & & & & & & & & & \\
\hline Eluate enzyme $7 / 29$ & 63 & - & - & $4 \mathrm{I}$ & - & - & 76 & 28 & 9I & . \\
\hline
\end{tabular}

Table 3. 'Cocktail' compositions representing approximate physiological substrate and effector concentrations*

Components

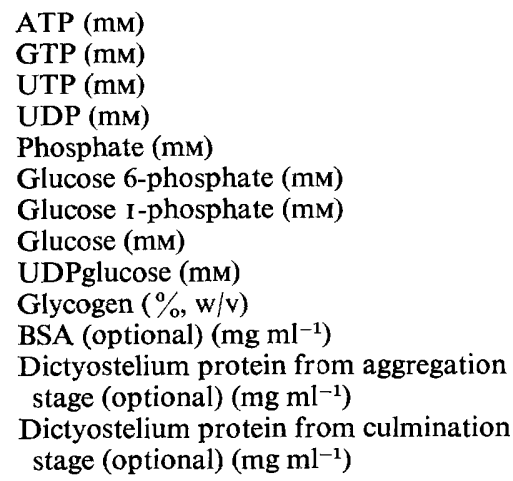

Differentiation stage

$\begin{array}{ccc}\text { Aggregation } & \text { Pseudoplasmodium } & \text { Culmination } \\ 0.4 & 0.5 & 0.3 \\ 0.05 & 0.1 & 0.1 \\ 0.05 & 0.05 & 0.1 \\ 0.12 & 0.12 & 0.12 \\ 3.0 & 3.0 & 3.0 \\ 0.025 & 0.050 & 0.075 \\ 0.005 & 0.010 & 0.015 \\ 1.25 & 1.875 & 6.25 \\ 0.20 & 0.40 & 0.67 \\ 0.57 & 0.57 & 0.57 \\ 14.3 & 14.3 & 14.3 \\ 13.5 & 13.5 & 13.5 \\ 17.0 & 17.0 & 17.0\end{array}$

* Wright (1973) and C. Rutherford (unpublished data).

mentation is involved. Raising the concentration of glucose 6-phosphate to above cellular levels released some of this inhibition, particularly for ATP and GTP. Except for ADP and GDP, the remaining inhibition at high glucose 6-phosphate concentrations could be released by raising the UDPglucose concentration to above physiological levels.

Neutralized sodium citrate at $\mathrm{I} \cdot \mathrm{O}$ or $\mathrm{O} \cdot \mathrm{I} \mathrm{mM}$ did not markedly affect activity at either cellular or higher levels of glucose 6-phosphate and UDPglucose.

To determine the combined influence of several possible effectors in vivo, 'cocktails' were prepared representing approximate cellular substrate and effector concentrations at three stages of differentiation (Table 3): each cocktail completely inhibited D-synthase. High levels of BSA or Dictyostelium protein did not release the inhibition caused by the cocktail.

Figures $5(a)$ and $5(b)$ show the double reciprocal plots for glycogen and UDPglucose 


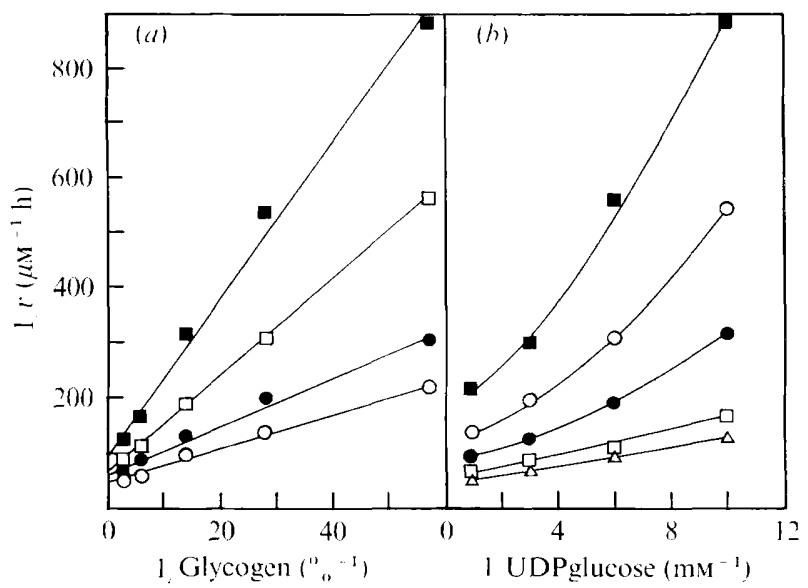

Fig. 5. Double reciprocal plots obtained using ammonium sulphate fraction enzyme. (a) Data plotted against reciprocal glycogen concentrations. Each curve represents a constant UDPglucose

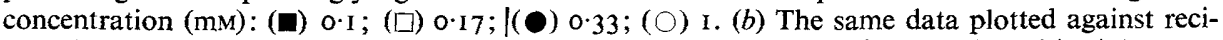
procal UDPglucose concentrations with glycogen concentrations as follows $(\%, w / v):(\mathbb{0}) 0.015$; (○) $0.030 ;(\bigcirc) 0.060 ;(\square) 0.15 ;(\triangle) 0.30$. Each point is an average of two measurements.

Table 4. Kinetic constants obtained from the double reciprocal plots of Fig. 5

$\begin{array}{lcc}\text { Constant } & \text { Calculated from I } / v v . \mathrm{I} / \text { glycogen } & \text { Calculated from } \mathrm{I} / v v . \mathrm{I} / \mathrm{UD} \\ V_{1}{ }^{*} & 29 \mathrm{nmol} \mathrm{h}^{-1} & 26 \mathrm{nmol} \mathrm{h}^{-1} \\ \bar{K}_{\mathrm{u}} & 0.18 \mathrm{mM} & 0.13 \mathrm{mM} \\ K_{\mathrm{ig}} K_{\mathrm{u}} & 0.028 \mathrm{mM} \% & 0.029 \mathrm{mM} \% \\ K_{\mathrm{g}} & 0.057 \% & 0.058 \%\end{array}$

* $V_{1}$ is the maximum velocity for $10 \mu \mathrm{l}$ ammonium sulphate fraction (300 $\mu \mathrm{g}$ protein).

obtained with the ammonium sulphate fraction, at 10 mM-glucose 6-phosphate. When the glucose 6-phosphate concentration was reduced to I mM, giving about $85 \%$ D-synthase activation, the pattern of the $\mathrm{r} /$ glycogen plots became hyperbolic, i.e. high glycogen levels inhibited the enzyme.

\section{DISCUSSION}

\section{Reaction mechanism}

The I/UDPglucose plots (Fig. $5 b$ ) are concave-upward at low glycogen levels. Such curvature, which is not consistent with any possible bi bi mechanism, may merely be due to the low levels of glycogen substrate. Plesner, Plesner \& Esmann (1974), for example, noted that apparent sigmoid curving occurs at low glucose 6-phosphate or UDPglucose concentrations.

If we consider our plots to be essentially linear, our results are similar to those obtained by Plesner et al. (1974) in their study of glycogen synthase from leucocytes. Following their reasoning, we consider that our double reciprocal plots are consistent with the rapid equilibrium random bi bi, ordered bi bi or Theorell-Chance mechanisms; the ordered bi bi and Theorell-Chance possibilities are restricted to cases where glycogen is the first reactant and second product of the reaction sequence. These mechanisms have initial rate laws of the form:

$$
\frac{V_{1}}{v}=\frac{K_{\mathrm{ig}} K_{\mathrm{u}}}{\mathrm{GU}}+\frac{K_{\mathrm{g}}}{\mathrm{G}}+\frac{\bar{K}_{\mathrm{u}}}{\mathrm{U}}+\text { const }
$$


in which, for all mechanisms, $\bar{K}_{\mathrm{u}}=K_{\mathrm{u}}\left(\mathrm{I}+K_{\mathrm{ig}} / K_{\mathrm{ig}}\right)$. For the rapid equilibrium random bi bi mechanism, const $=\mathrm{I}$, and for the Theorell-Chance and ordered bi bi mechanisms, const $=\mathrm{I}+K_{\mathrm{g}} / K_{\mathrm{ig}}$ '. G and $\mathrm{U}$ are glycogen and UDPglucose concentrations, respectively. Kinetic constants are as defined by Cleland (1963); the $\mathrm{g}^{\prime}$ subscripts indicate these constants refer to glycogen as the back reactant.

Straight lines were fitted by eye to the double reciprocal plots; for the I/UDPglucose plots, the points for the highest I/UDPglucose value were rejected. Slopes and intercepts were calculated for these lines, and from these parameters the kinetic constants listed in Table 4 were obtained. These constants hold for the rapid equilibrium random bi bi mechanism, for which the initial rate equation has its simplest form. Since the values obtained from the I/glycogen and I/UDPglucose plots are in reasonable agreement, we are confident of the consistency of our data and curve fitting.

In fitting our results to possible kinetic mechanisms, we assume that substrates are freely diffusible and available to the enzyme; these assumptions may not hold for glycogen synthase in relation to the glycogen substrate. Huang \& Cabib (1974), McVerry \& Kim (1974) and Salsas \& Larner (1975) have suggested several possible complications concerning the kinetics of this system. Their considerations may explain some non-linearities in their own double reciprocal plots, as well as in our results.

Several investigators have examined the reaction mechanism of synthase from diverse sources. Plesner et al. (1974) concluded that the D-synthase of polymorphonuclear leucocytes acts by a rapid equilibrium random bi bi mechanism. McVerry \& Kim (1974) concluded that $\mathrm{D}$-synthase of rat liver acts by a random bi bi mechanism, though their I/glycogen plots had a convex-upward curvature not predicted for this mechanism. Huang \& Cabib (1974) examined yeast synthase that was 70 to $80 \% \mathrm{D}$ form and drew their $\mathrm{r} /$ glycogen and $\mathrm{r} / \mathrm{UDP}$ glucose plots as biphasic straight lines. Salas \& Larner (1975) studied I-glycogen synthase from rabbit muscle; their double reciprocal plots showed straight lines for each case.

\section{Effector studies}

Our glucose 6-phosphate activation studies indicate that the interaction of enzyme and glucose 6-phosphate is affected by $\mathrm{pH}$ but only slightly by UDPglucose concentration. At pH 6.5 the enzyme activity is half-maximum at about 0.04 mM-glucose 6-phosphate but at $\mathrm{pH} 8.5$ half-maximum activity is observed at $0.3 \mathrm{~mm}$-glucose 6-phosphate. Our activation data at $\mathrm{pH} 8.5$ compare well with those of Wright \& Dahlberg (1967). Under comparable conditions, they found half-maximum activity at about $0.2 \mathrm{~mm}$-glucose 6 -phosphate.

Several authors have found that ATP and UDP inhibit the synthases from diverse sources (Stahlmans \& Hers, I973). In Dictyostelium, glucose 6-phosphate and UDPglucose release inhibition only at levels which are above their reported physiological concentrations, suggesting that such regulation does not occur in vivo. This result contrasts with that of Rothman \& Cabib (1967), who concluded that physiological levels of glucose 6-phosphate could release nucleotide inhibition in yeast cells.

'Cocktail' experiments, which attempted to reconstruct the physiological concentrations of various metabolites and of cellular protein, suggest that the D-synthase is inactive under physiological conditions. We hold the reservacion that compartmentation effects must be considered in the interpretation of reconstruction experiments. For example, the D-synthase in vivo is associated with glycogen, which becomes localized in the presumptive spore cell types and spore cells during differentiation. Inorganic phosphate, on the other hand, accumulates in the presumptive stalk cells (Rutherford, I976).

The hypothesis that glycogen synthase activity in vivo may be due to the presence of 
I-synthase is under investigation. If this is so, it would agree with the general finding for mammalian systems (Stahlmans \& Hers, 1973). For Dictyostelium, data from crude extracts (Rosness, Gustafson \& Wright, 197I) suggest that total synthase activity (D+I) remains constant, while the proportion of D-synthase activity increases during development; these data implicate a conversion of enzyme forms as a mechanism for decreasing synthase activity during development.

We thank Drs Liselotte and Igor Plesner for many helpful comments during this investigation. We also thank Emil Alter of Stein, Hall and Company for a gift of Superlose.

This investigation was supported by Public Health Service grants AGoo433 and AGoo26o from the National Institute of Child Health and Human Development, and General Research Support Grant 5Sor RRo57 I.

\section{REFERENCES}

Algranati, I. D. \& CABIB, E. (I962). Uridine diphosphate D-glucose-glycogen glucosyltransferase from yeast. Journal of Biological Chemistry 237, 1007-1013.

BERNFELD, P. (195I). Enzymes of starch degradation and synthesis. Advances in Enzymology 12, 379.

Cleland, W. W. (I 963). The kinetics of enzyme-catalyzed reactions with two or more substrates or products. Biochimica et biophysica acta 67, 104-137.

Dubois, M., Gilles, K. A., Hamilton, J. K., Rebers, P. A. \& Smith, F. (is56). Colorimetric method for determination of sugars and related substances. Analytical Chemistry 28, 350-356.

Firtel, R. A. \& Bonner, J. (1972). Developmental control of $\alpha$-I,4-glucan phosphorylase in the cellular slime mold Dictyostelium discoideum. Developmental Biology 29, 85-103.

Hames, B. D. \& Ashworth, J. M. (I974). The metabolism of macromolecules during differentiation of myxamoebae of the cellular slime mould Dictyostelium discoideum containing different amounts of glycogen. Biochemical Journal 142, 30I-3 I 5.

Huang, K. P. \& CABIB, E. (1974). Separation of the glucose-6-phosphate independent and dependent forms of glycogen synthetase from yeast. Biochemical and Biophysical Research Communications 49, 1610-16I6.

Jones, T. H. D. \& WRIGHT, B. E. (1970). Glycogen phosphorylase of Dictyostelium discoideum. Journal of Bacteriology 104, 754-761.

Lowry, O. H. (1957). Protein estimation with the Folin-Ciocalteau reagent. Methods in Enzymology 3 , $448-450$.

Marshall, R., SARgent, D. \& Wright, B. E. (1970). Glycogen turnover in Dictyostelilim discoidelim. Biochemistry 9, 3087-3094.

MCVerRy, P. H. \& Kim, K. H. (1974). Purif.cation and kinetic mechanism of rat liver glycogen synthetase. Biochemistry I3, 3505-35II.

Plesner, L., Plesner, I. W. \& Esmann, V. (I974). Kinetic mechanism of glycogen synthetase D from human polymorphonuclear leukocytes. Journal of Biological Chemistry 249, III9-1125.

Pontis, H. G. \& Leloir, L. F. (I962). Measurement of UDP-enzyme systems. Methods of Biockemical Analysis 10, 107-1 36 .

Rosness, P. A. \& WRIGHT, B. E. (1974). In vivo changes of cellulose, trehalose ard glycogen durirg differentiation. Archives of Biochemistry and Biophysics $164,60-72$.

Rosness, P. A., Gustafson, G. \& Wright, B. E. (197I). Effects of 3'5'-AMP and 5'-AMP on glycogen degradation and synthesis in Dictyostelium discoideum. Journal of Bacteriology Io8, I329-1 337.

Rothman, L. B. \& CABIB, E. (1967). Allosteric properties of yeast glycogen synthetase. II. The $\in$ ffcct of $\mathrm{pH}$ on inhibition and its physiological implications. Biochemistry 6, 2107-21 12.

RUTHERFORD, C. L. (I976). Cell specific events occurring during development. Journal of Embryology and Experimental Morphology 35, 335-343.

Rutherford, C. L. \& WRIGHT, B. E. (I971). Regulation of nucleotide metabolism during differentiation in Dictyostelium discoideum. Journal of Bacteriology 108, 269-275.

SAlSAS, E. \& LARNER, J. ( I 975). Kinetic studies on muscle glycogen synthetase. Journal of Biological Chemistry 250, 347I-3475.

Stahlmans, W. \& Hers, H. G. ( I973). Glycogen synthesis from UDPG. In The Enzymes, 3rd edn, vol. 9, pp. 309-36I. Edited by P. D. Boyer. London and New York: Academic Press.

WARD, C. \& WRIGHT, B. E. (1965). Cell wall synthesis in Dictyostelium discoideum. I. In vitro synthesis from uridine diphosphoglucose. Biochemistry 4, $2021-2026$.

Wright, B. E. (1973). Critical Variables in Differentiation, p. 70. Englewood Cliffs, New Jersey: Prentice Hall.

Wright, B. E. \& Dahlberg, D. (1967). Cell wall synthesis in Dictyostelium discoideum. II. Synthesis of soluble glycogen by a cytoplasmic enzyme. Biochemistry 6, 2074-2079. 